\begin{tabular}{|l|l|l|}
\hline \multicolumn{2}{|c|}{ PublisherInfo } \\
\hline \hline PublisherName & $:$ & BioMed Central \\
\hline \hline PublisherLocation & $:$ & London \\
\hline \hline PublisherImprintName & $:$ & BioMed Central \\
\hline \hline
\end{tabular}

\title{
Heterochromatin boundaries
}

\begin{tabular}{|l|l|l||}
\hline \multicolumn{2}{|c|}{ ArticleInfo } \\
\hline \hline ArticleID & $:$ & 4176 \\
\hline \hline ArticleDOI & $:$ & $10.1186 /$ gb-spotlight-20010814-01 \\
\hline \hline ArticleCitationID & $:$ & spotlight-20010814-01 \\
\hline \hline ArticleSequenceNumber & $:$ & 247 \\
\hline \hline ArticleCategory & $:$ & Research news \\
\hline \hline ArticleFirstPage & $:$ & 1 \\
\hline \hline ArticleLastPage & $:$ & 2 \\
\hline \hline & & RegistrationDate : 2001-08-14 \\
ArticleHistory & $:$ & OnlineDate \\
\hline \hline ArticleCopyright & $:$ & BioMed Central Ltd2001 \\
\hline \hline ArticleGrants & $:$ & \\
\hline \hline ArticleContext & $:$ & 130592211 \\
\hline \hline
\end{tabular}




\section{Jonathan B Weitzman}

Email: jonathanweitzman@hotmail.com

Chromosomes are composed of functionally distinct domains separated by chromatin boundaries. In the August 10 Science, Noma et al. define the boundaries of the heterochromatin domain at the matingtype locus (mat) in fission yeast (Science 2001, 293:1150-1155). They used chromatin immunoprecipitation (ChIP) and PCR analysis to scan the entire mat region (about 47 kilobases). Methylation of lysine 9 of histone $\mathrm{H} 3$ and the Swi6 protein were both enriched in a 20kb interval that contains the mat $2 / 3$ silent cassettes. The inverted repeats IR-L and IR-R mark the boundaries of this heterochromatin domain. In contrast, methylation of lysine 4 of histone H3 showed an inverse pattern and was excluded from the mat $2 / 3$ region. Noma et al. show that deletion of the boundary IR-L and IR$\mathrm{R}$ repeats resulted in spreading of both H3-Lys9 methylation and Swi6 beyond the normal heterochromatin domain (up to 8 kilobases). Thus, distinct $\mathrm{H} 3$ methylation patterns define euchromatic (H3-Lys4-Methyl) and heterochromatic (H3-Lys9-Methyl) domains. The boundaries of these domains are dictated by the presence of insulating elements.

\section{References}

1. Chromosomal boundaries in Saccharomyces cerevisiae.

2. Science, [http://www.sciencemag.org]

3. Multiple epigenetic events regulate mating-type switching of fission yeast.

This PDF file was created after publication. 